\title{
POMARINE JAEGER AT LAC LA PLONGE, SASKATCHEWAN
}

\author{
BURKE KOROL, Department of Crop Science and Plant Ecology, University \\ of Saskatchewan, Saskatoon, Saskatchewan, S7N OWO and ROBERT \\ WAPPLE, \#3 - 513 Dufferin Avenue, Saskatoon, Saskatchewan. S7N 1 C2
}

In the spring of 1993 the authors were hired to conduct forest songbird surveys for the Forest Bird Program, Canadian Wildlife Service (CWS). On 10 June unsettled weather and occasional rain in the Beauval area caused us to cancel our daily survey. This "down time" allowed us to rent a boat from Darsana Lodge at the northwest corner of Lac la Plonge and go fishing for the day.

Fishing was slow but Robert managed to catch two Lake Trout around $1100 \mathrm{~h}$. After lunch on the wavy lake, we headed back toward camp. At 1345 h, Robert spotted a large, dark, gull-sized bird flying with two "whiteheaded" gulls about $500 \mathrm{~m}$ to the east. In order to confirm the dark bird's identity, we quickly reeled in our lines and pursued it. As we neared the three birds they alighted on the water and we soon found ourselves viewing a light phase adult Pomarine Jaeger in breeding plumage.

Soon all three birds took flight and began foraging over the water approximately $50 \mathrm{~m}$ from our boat. Each of us viewed the jaeger through $8 x$ binoculars and we could clearly see the following field marks: black cap, yellow sides of the nape, sooty brown back, white rump with faint barring, off-white markings on the upper and lower surfaces of the primaries, complete breast band, whitish belly, black feet and grey- brown barring on the axillars. The most distinguishing field marks were the two stubby, twisted feathers that protruded about $1 \mathrm{~cm}$ from the end of the tail. Weather conditions at the time of observations were: approximate $10^{\circ} \mathrm{C}$, winds east at approximately $30 \mathrm{kmph}$, overcast with light rain.

The jaeger's flight was heavy but direct. Its body looked bulkier than the nearby Herring Gulls and its wings appeared shorter and broader. We approached to within $5 \mathrm{~m}$ of the flying jaeger which offered us excellent views from many different angles. After about five minutes of observation we tried to attract it even closer with some food. A bun was torn up and tossed in the water. At first the jaeger seemed uninterested but the reaction from a growing group of 10 Herring and two California Gulls drew its attention. Burke used fish entrails to feed Mew and Herring Gulls in the Wollaston Lake area in the spring of 1989 and decided to try this with the jaeger. We began to throw fish parts, on the water and the fun began! The jaeger was incredibly daring, immediately snatching up our offerings. It would hover $1 \mathrm{~m}$ above us while the growing mob of 35 Herring and California Gulls kept their distance. Deciding not to throw the fish parts Burke merely held them up in the air. On one occasion the jaeger took trout eggs from his hand after nipping his fingers twice and briefly setting its 
left foot on his index finger. We now realized how much we regretted leaving the camera at camp!

For the next 15 minutes the birds hovered above us and caught our offerings in midair. The jaeger ate most of the entrails from both of the approximately 2-kg Lake Trout. It did not show any aggression towards the gulls as we expected, but they did not challenge the jaeger for food and kept a respectable distance. We assumed that the bird was satiated when it eventually left us at $1415 \mathrm{~h}$, landing on the water $200 \mathrm{~m}$ northeast of us. We fed the rest of the fish parts to the gulls which were considerably bolder now that the jaeger had left the area. Once all the scraps were gone, the jaeger was no longer visible.

Our experience with the jaeger on Lac la Plonge left us quite excited and when we returned the boat to Darsana Lodge we told the lodge owners, Carl and Marg Boychuck, about our encounter. They were quite interested and we showed them several illustrations of Poma- rine Jaegers from our field guides. We spoke to Carl on 12 June and he told us that some other fishermen had an odd experience while fishing on Lac la Plonge on 11 June. The fishermen told him of a "black and white seagull" that came and landed on the bow of their boat while they were fishing. Later, on 30 June, Marg reported that the jaeger was seen as late as 19 June, indicating that the bird may have been in the area for as long as ten days.

Godfrey noted that Pomarine Jaegers are very rare in Saskatchewan. ${ }^{1}$ Our sighting constitutes only the twelfth known record of this species in Saskatchewan. ${ }^{9}$ The previous eleven records are listed below:

Acknowledgements Thanks are extended to A.R. Smith (CWS) for providing past records and editorial comments. Thanks also to K.A. Hobson (CWS) for providing us with the opportunity to work in the area and for reviewing this article. The hospitality of Carl and Marg Boychuck at Darsana Lodge, Lac la Plonge, was greatly appreciated.

\begin{tabular}{|c|c|c|c|}
\hline Date & Location & Comment & Reference \\
\hline 9 Nov 1922 & Yellow Grass & $\begin{array}{l}\text { first Saskatchewan } \\
\text { specimen }\end{array}$ & 10 \\
\hline 22 Jun 1942 & $\begin{array}{l}\text { Dillon River at Peter } \\
\text { Pond Lake }\end{array}$ & $\begin{array}{l}\text { harassing Ring-billed } \\
\text { Gulls }\end{array}$ & 11 \\
\hline 20 Apr 1944 & Torch River & & 6 \\
\hline Summer 1966 & Lake Athabasca & & 3 \\
\hline Summer 1966 & Wollaston Lake & & 3 \\
\hline 30 Dec 1976 & $\begin{array}{l}\text { Spruce River at Hwy. } \\
263\end{array}$ & $\begin{array}{l}\text { second Saskatchewan } \\
\text { specimen }\end{array}$ & 12 \\
\hline 1 May 1984 & Last Mountain Lake & & 2 \\
\hline 31 Oct 1985 & Gardiner Dam & & 4 \\
\hline 23 Jul 1986 & Dore Lake & $\begin{array}{l}\text { followed owner of } \\
\text { Michel Point Lodge } \\
\text { across lake }\end{array}$ & 7 \\
\hline 5 Nov 1986 & Last Mountain Lake & & 5 \\
\hline 22 Sep 1990 & Candle Lake & & 8 \\
\hline
\end{tabular}


